\title{
Whose Citizenship? Social Conflict over Property in the United States
}

\author{
Harvey M. Jacobs \\ University of Wisconsin-Madison, USA; Radboud University Nijmegen, The Netherlands; emeritus \\ E-mail: jacobs.harvey.m@gmail.com
}

Land ownership and the rights in property are central to the American character, having originated as part of the colonial dialogue that led to the American revolution. Yet there has also been substantial social conflict over who has claims to property, and in whose interest. This article presents an interpretive history of citizenship claims to land and property from the colonial period to the present. It argues that a theme in this history is an ever expanding realm of citizenship claims against the individual owner, most markedly since the beginning of the twentieth century. The emergence of the modern environmental movement and a counter so-called private property rights movement in the 1970s forward has accentuated this social conflict. The future likely holds increased conflict in an era of social and political polarisation. The outcome is uncertain, and will depend on democratic dialogue among those with strongly opposing perspectives.

Keywords: Land ownership, rights in land, private property, social conflict, American history.

\section{Introduction}

The United States is a country whose very founding linked the concept of citizenship to the right to own and control property in land: that is, to hold and control private property (if one were a free, white man). This idea has remained a central part of the country's mythology about itself, and contributed to key policy developments throughout the centuries (e.g. the Homestead Act of the mid-1800s which provided for 'free' land to settlers of the American west). Up until the beginning of the twentieth century urban and rural landowners had relatively unrestricted rights to use their land as they pleased. However, with the urbanisation that began in the late 1800s and accelerated in the early 1900s public land use controls (e.g. zoning) were introduced that began a process of seeking to re-balance individual and social rights in land. By the 1930s these land use controls spread to America's rural areas. However even up until the 1960s the individual land owner still had a relatively unrestricted right of land use.

The emergence of the environmental movement in the late 1960s changed this balance. Part of this movement was a broad and systemic critique of private land ownership and how such ownership led to widespread environmental degradation. As a result of the movement's strength and public support a wide variety of national, state and local laws were passed addressing environmental concerns; the impact of these laws was to constrict the property rights of individual land owners. 
In reaction to these laws a counter social movement emerged advocating for individual landowner rights. This counter movement based their advocacy on both American history and twentieth century legal decisions. Over the ensuing decades both movements - the environmental movement and the so-called private property rights movement - have grown stronger. ${ }^{1}$

In the early twenty-first century there is a heated debate about citizenship and property. Private property rights advocates argue that individual owner rights in property have been so diminished by environmental laws as to fundamentally weaken the link between property and citizenship, and thus to erode a core concept of what it means to be an American. Environmental advocates argue that a new concept of citizenship needs empowering - that of the environment itself and the rights of future generations - and that this is not in conflict with essential ideas about American identity (see, for example, two edited volumes from 1995 both of which contain arguments reflecting these two perspectives: Echeverria and Eby, 1995, Yandle, 1995).

There is a large body of scholarship - legal, sociological, and policy - including by this author, on this debate (see the references section of this article). This article adds to this literature by framing it as a long-standing debate over the nature of citizenship, that is over who has claim to decide what may or may not occur on a particular piece of property. The article accomplishes this by first setting the colonial and nineteenth century context in which social and legal ideas about the ownership and control of property emerged. In this context, ownership and control of land was considered by many to be central to the creation of American democratic institutions. As such, many of these ideas were embedded in America's founding documents, but so were ambiguities which later came to the fore. The twentieth century is then defined as a period of significant technological, social, and institutional change. Thus began a century-long process of actively redefining who owned and could control property, creating an ever more social context for such ownership and control. The twentieth century ends with uncertainty for the future. Social claims to property have created doubt about the centrality of property as an American institution, and with this doubt evermore social and policy conflict. In conclusion I suggest that there will never be final answers to the debate, only continuous social-democratic dialogue which will yield new, though temporary, resolutions reflective of new technological, social and institutional conditions.

\section{The colonial and nineteenth century context}

Citizenship and the ownership and control of land is an issue deeply embedded in the American psyche, and has helped shape and define the national character. The seventeenth and eighteenth century history of the US is often portrayed as migrations spurred by the issues captured in the first amendment of the US Constitution's Bill of Rights - a search by oppressed peoples for civil freedoms (of speech and assembly) and religious freedom. These issues were key to colonial immigrations, but it is equally true that migration was spurred by a desire for access to freehold land unavailable in Europe. The US was settled by people, first Europeans but continuing through to today, searching for religious and civil freedom and for access to land (Ely, 1992).

In America's early years western European countries were still structured under the vestiges of feudalism. America was a place where any white male immigrant had the 
potential to own land. America was the land of opportunity. To be a full American citizen was to own and control private property. This meant, of course, that swathes of 'others' were excluded from citizenship - women, racial minorities, and sometimes religious minorities (e.g. see Collier, 1992).

As the revolutionary period took shape, influential framers argued that it was as much for the right to own and control land as anything else that the new political experiment - American democracy - was coming into being. For example, James Madison writing in Federalist Paper No. 54, during the debate about the ratification of the US Constitution, argued that 'government is instituted no less for the protection of property than of the persons of individuals' (Hamilton et al., 1961 [1788]: 339). Many others concurred. ${ }^{2}$

Thomas Jefferson, the author of the US Declaration of Independence and the third president of the country, had an idea about the so-called yeoman farmer that drew from the sentiments expressed by Madison. According to Jefferson the family farmer who owned and controlled his own land was the foundation and bastion of the new American democracy. Ownership of land gave the owner economic and political liberty, and thus standing as a citizen (Gilreath, 1999).

But this view of the relationship of property to democracy and citizenship, and the fact of asserting property's primacy, was itself challenged during this period, most notably by Benjamin Franklin. Franklin, the renowned scientist, inventor, publisher and revolutionary-era ambassador to France, noted with force that 'private property is a creature of society, and is subject to the calls of that society whenever its necessities require it, even to the last farthing' (Franklin, 1907 [1789]: 59). Franklin was not alone in these sentiments; he too shared them with others. When looked at closely the meaning of land and private property and their relationship to citizenship and democratic structure were contentious issues from the very beginning of America's founding (Ely, 1992; Jacobs, 1999). The matter of 'whose citizenship' with regard to land is embedded in the earliest discourses about American character and the relative balance of the individual's and others' rights in property.

The country's founding national documents reflect this lack of consensus. In 1776 the American Declaration of Independence promised Americans 'life, liberty and the pursuit of happiness.' Thomas Jefferson drew this idea from political philosopher John Locke, who called for life, liberty and property. Jefferson wanted to copy Locke's phrase. Jefferson's idea was to create the nation of yeoman farmers. But in its final form the Declaration's language reflected disagreements about what would be promised to (white, male) citizens of the new country.

In 1787 the US Constitution was adopted without any specific mention of land related property. It was not until the adoption of the US Bill of Rights in 1791 that the disagreements among the framers found a degree of consensus in the wording for the so-called takings clause (the expropriation clause), the final twelve words of the Fifth Amendment '.. nor shall private property by taken for public use, without just compensation.'

Here the Founders formally recognised: the existence of private property, an action denoted as taken, a realm of activity which is public use, and a form of payment specified as just compensation. When private property exists, it may be taken by government, but only for a denoted public use, and when just compensation is provided. 
This provision allows for expropriation of private land for public highways, schools, parks, and other public activities, but requires that the owner be paid fairly for the land taken. But the exact meaning of this phrase to those who crafted it is unclear (see, for example, Bosselman et al., 1973; Epstein, 1985; Ely, 1992; Treanor, 1995). We do not know exactly when a taking has occurred, what defines a public use, what constitutes just compensation, or even what is considered private property. We do know, though, that in a new country with a small population and a large territory citizens (those who owned property) had relatively broad control over the use of their land.

Continued controversy over citizenship and land emerged relatively quickly in U.S. history. By the middle of the nineteenth century two issues presented themselves. The first came out of the American Civil War (1861-1865). The emancipation of slaves in 1863 by President Abraham Lincoln led to a post Civil War period known as Reconstruction (1865-1877). During this period, efforts began to redistribute confiscated plantations in the American south to former slaves. The phrase used to capture this land reform phenomenon was 'forty acres and a mule' (see, for example, Oubre, 1978). The intent and understanding was that by imbuing black men with land ownership it would embed their claims as citizens. The second occurred in the same period, and provided for the so-called homesteading of the American west. The national Homestead Act of 1862 was a way for a broad range of people - newly arrived immigrants, landless farmers, even single women or former slaves - to get access to public land (160 acres) and transform it into private land (Gates, 1936, is one of many sources that discuss this landmark legislation and its impact and implications). Through ownership, claims to citizenship began to be established (though they were not always fully realised: Foner, 1992).

But the U.S. in this period was still a rural nation, and land ownership was still a primary basis for defining who was (and who was not) a citizen. Up through the nineteenth century landowners were largely free to use their land as they pleased. Real change to the status of property, and thus to the challenge of citizenship in land, came in the twentieth century, the period when new technological developments changed how Americans lived their lives, and held and used property. In the early twentieth century America went from a rural to an urban nation. The mass immigrations from Europe combined with the explosion of industrialisation to bring waves of individuals to the cities. As this occurred new ideas about land, ownership and citizenship claims began to change.

\section{The twentieth century technological, social, and institutional revolution}

In 1903 the Wright brothers invented mechanical flight. Within a very few years the airplane went from a novelty to commercial development. If ownership meant owning air rights to the heavens above, then every time an airplane flew over anyone's property it was guilty of trespass. The airplane had entered the property as surely as if the pilot had jumped over a fence and kept walking. A technological change made a pre-twentieth century definition of private property no longer socially functional. If individual land owners could claim trespass of and demand compensation for their property by airplanes, air travel would become either too cumbersome or too expensive. 
What happened? During the first half of the twentieth century, the US courts solved this problem by 'public-izing' air rights above a certain elevation without requiring compensation under the Fifth Amendment (Bell, 1928-1929; Johnson, 1965). The courts reappropriated airspace to the public sphere so individual owners no longer owned est usque ad coelum - all the way to heaven. In effect, the courts created a new commons where one had not existed before. The creation of this new commons responded to changing social needs pushed by changing technology.

Continuing through the twentieth century American landowners saw the very definition of property change in response to new inventions and changing social values. As society understood the impact of individual land use decisions upon neighbours and society at large, and as new ideas about ourselves and others developed, Americans continued to reconfigure the foundational property rights bundle (Bosselman et al., 1973).

In addition the twentieth century also brought forth the period of modern land use and environmental regulation. Through these property and claims to property entered another century-long period of social contestation.

In 1920, for the first time, the US Census recorded more people living in cities than in the countryside. The rapid growth of American cities caused significant land use problems, as individual owners sought to maximise the potential of their land, while the city found itself pressured to exercise its traditional authority to protect the public's health, safety, and welfare. This was the period of muckraking journalism, which chronicled the poverty of immigrants crowded into tenements in New York City neighbourhoods with densities exceeding even that of Calcutta, India, often absent access to sanitation facilities, clean water, light, and air (Riis, 1890, is a pioneering book about this phenomenon). Out of these conflicts grew zoning (Gordon, 1931; Revell, 1999).

Today, zoning is common. But at the time of its invention, it was revolutionary. It established a public sector framework for land use that proscribed the property rights of owners absent compensation (Hirt, 2015). In so doing, it established the rights of a broad citizenry upon an individual's land.

New York City is generally credited with inventing comprehensive zoning in $1916 .{ }^{3}$ Within a decade it had spread across the US, because it filled a need that cities had for rationalising land use management. Then in the 1930s zoning began to expand to rural America (Warp, 1941-1942; Wilson, 1957-1958). It began to be ubiquitous. Until the second half of the twentieth century, most land use regulations looked similar to zoning in its initial form. But then things changed again. As America began to suburbanise, zoning was stretched to fit new land use circumstances, and new social values about land and natural and environmental resources. This became especially pronounced with the rise of the modern environmental movement.

Conceptually land use and environmental planning, policy and management (through devices such as zoning) are premised on the need for individual property rights to yield to a collective definition of the public interest. Such planning and policy argues that an unfettered right to exercise individual property rights does not serve the greater public good. As some environmentalists articulate it, land use and environmental problems arise precisely because of the way property rights are privately held and managed. Individuals are making land use management decisions which do not take 
into account the broader public interest and a more expansive economic calculus. These arguments are an updating and restatement of those that led to the very invention of zoning.

A litany of common land use and environmental issues - air pollution, river and lake pollution, farmland loss in the urban fringe, suburban sprawl, destruction of historic buildings, downtown deterioration, to name just a few - have all been depicted as issues that arise from a version of Hardin's 'tragedy of the commons' (Hardin, 1968; Sinden, 2007). In these instances, the tragedy is that individual landowners make decisions that are economically and socially sensible to them, but are not judged to be as sensible to the broader public. To put the same point in the terms of classical economics, each individual pursuing their own self-interest does not yield the greater social interest. ${ }^{4}$

In direct opposition to this perspective and this version of the environmental movement there emerged what has become known as the property rights movement (Jacobs, 1995, 1998; Marzulla, 1996). According to the property rights movement, the intent of key American founders and the principles embodied in the founding documents of the US make the protection of private property rights a central element of the American political and social contract.

The property rights movement's framing of American history comes together with a particular view of twentieth century public policy and law. From their perspective the last 100 years presents a story that appears to move ever farther away from a view of property rights as integral and central to liberty and democracy. Instead, what appears is a story in which government and other citizens are allowed ever increasing authority to intrude upon an individual's land.

While the private property rights movement was formally born in 1988 its intellectual antecedents originate at least with the rise of the modern environmental movement (e.g. McClaughry, 1975, 1976). What has developed since 1988 is a national coalition targeting national, state, and local land use and environmental laws, policies and programs, such as the those for endangered species protection, smart growth, farmland and wetland protection, etc. (Jacobs, 1995). This coalition argues that these attempts at the management and restriction of an individual's land are un-American, inefficient, and ultimately, ineffective.

The property rights movement has pursued a multi-level strategy to achieve their objectives. In their early years, this strategy was focused at the national level, but there was little outcome for this activity. They then shifted towards state legislatures and here they found fertile ground for their arguments and their ideas.

In the 1990s every state in the US considered state-based legislation in support of the policy position of the property rights movement, and twenty-seven states passed such legislation (Emerson and Wise, 1997). These were both so-called 'red' (conservative) and 'blue' (liberal) states. And following the US Supreme Court's Kelo decision (see note 6), forty-three states adopted so-called anti-Kelo laws promulgated by this movement (Jacobs and Bassett, 2011).

So it is that these critics of this evolution of social control - of the expansion of citizenship claims to land - ask Americans to take a deep breath and step back (Epstein, 1985; Bethell, 1998). They argue that the fallacy in seeing modern society as a series of Garrett Hardin-style tragedy of the commons situations is that society (government) is able 
to continually justify a restriction/removal of property rights every time a new land use and environmental problem gets identified. Government can reconfigure who has a claim on land and that there is no reasonable end in sight. Property rights advocates identify at least two problems with this: when what an individual owns and controls is only what the government says he or she controls, does private property really exist? And what about the literal and figurative property-democracy social contract which forged and underlies the US (Sandefur, 2006; Jacobs, 2010)?

Another way to understand the reconfiguration of property rights in response to changing technology and changing social values, and the continuous expansion of regulation, is the continuous expansion of parties with claim to land. If in the eighteenth and nineteenth centuries land was largely the purview of the owner to do with as he or she pleased, the story of the twentieth century is that a variety of interests have laid claim to land, and argued that the owner's traditional rights have to be reshuffled to include their interests and claims. Most obviously, this expansion includes government (in its various forms and layers) asserting its claim through the need to protect the public health, safety, and welfare.

But this has not been a one-sided story. The private property rights movement has a (strong?) basis in the twentieth American law for their position. Early in the twentieth century the US Supreme Court took up the issue of whether there was a limit to how much the government can regulate private land. In the 1922 case of Pennsylvania Coal Co. v. Mahon (Pennsylvania Coal Co. v. Mahon, 1922), US Supreme Court Justice Oliver Wendell Holmes wrote: 'The general rule is that while property may be regulated to a certain extent, if regulation goes too far it will be recognized as a taking' (260 U.S. 393, 1922: 415). This sentiment would seem to support the position of the property rights movement - regulation that is too onerous will be viewed by the courts as equivalent to physical expropriation and while allowed will require the regulating unit to provide compensation to those impacted. But the Court did not specify the precise place where the unacceptable limits of the regulation occurred.

Just a few years later, in 1926, the US Supreme Court took up the question of whether zoning itself was constitutional, and even if it was whether it was an example of regulation that 'goes too far'. In the landmark case of Village of Euclid v. Ambler Realty, Co (1926), the Court found that zoning was a constitutional exercise of governmental authority, and it did not go 'too far' (272 U.S. 365, 1926).

Since then political, policy, and judicial practice has been to largely (though not completely) back public regulatory activity as not crossing the line identified by Justice Holmes. ${ }^{5}$ For example, as the twenty-first century began, the US Supreme Court recognised the legitimate and important role of public regulation over land where there are conflicting claims between owners, neighbours, environmentalists, and the government (Tahoe-Sierra Preservation Council, Inc. v. Tahoe Planning Agency, 2002).

\section{The future}

Property is a complex social institution. In the US individuals and communities have strong emotional attachments to particular parcels and places, and for many people the ownership of private property remains one of the (if not the) primary economic assets 
acquired and managed in a lifetime. As such, individuals tend to have strong interest in the integrity of their property rights bundle. At the same time, many people seem to have an inherent understanding of the need to limit the exercise of (others) property rights through the use of public mechanisms. How can these tendencies be balanced?

What we can expect in the US is evermore social conflict over property rights, as one group with resources seeks to secure more quality of life values (controlled peri-urban growth, undivided farmland, pure trout streams, vibrant downtowns) and one group with some but marginal resources seeks to protect that sliver of investment they have in the American dream through investment in property (whether these be farmland owners, ranchers, wetland owners, or the owners of 'blighted' downtown neighbourhoods slated for redevelopment even when these neighbourhoods and homes may be socially and economically viable). ${ }^{6}$ An era of intensified social conflict is upon us, and one of its expressions will be heightened conflict over property rights.

While property matters to everyone who owns property, as an individual gets wealthier, the component of that person's financial profile directly tied to property decreases. While for the middle and lower middle class, the ownership of property is the primary form of wealth, for the upper middle class and wealthy, property is only one part of how they own and invest to secure their wealth (Geisler, 1995).

The impact of all this for land policy is profound. If a proposed land use or environmental program is going to affect property rights, it matters how important those property rights are. If those being affected are wealthier, they can, quite literally, absorb the impact; it matters less to them. If those being affected have only their landed property, then land policy (land use regulations) which proposes to take the value of that property for larger social values are more important to the individual. These individuals have a significant incentive to resist those regulatory efforts and work to preserve the integrity of their property rights bundle.

Social scientists have long noted that property owners who tend to support the development and implementation of land use and environmental policies and programs are those who can, quite literally, afford them. And they have noted that an upward shift in economic circumstances brings a shift in focus to the promotion of a set of quality of life values which can become translated into regulatory efforts to shape the use of other people's private property in the interest of pursuing larger, social values such as of environmental protection, growth management and smart growth (e.g. Heiman, 1988).

During the twentieth century the property rights bundle experienced waves of assault. At first the assault was a function of new technology and rapid urbanisation. These phenomena continued through the century and were then joined in the century's last half by an assault borne of changing social values, rooted in new attitudes about racial, gender, and then environmental relationships. With each wave of assault the integrity of the individual's property rights bundle was diminished.

Each of these assaults represents a change driven by a threat. In the early part of the century city spaces were changing as a function of inter- and intranational immigration; traditional ideas about property did not seem to work as these changes occurred. In the mid-century, property seemed to be a barrier to ever mounting calls for legal and social change in racial relationships. In the late century, claims to property's 
integrity appear to clash with new scientific findings about eco-system functioning and maintenance.

Will there be new challenges to property? Yes. As technology continues to develop, it will present continuing challenges to how Americans live and their concepts of property. And as society continues to develop, Americans will continue insisting that property be reshaped as old conceptions of property hold back the liberation and social integration of peoples and others once deemed invisible or irrelevant, or at least less deserving than property itself. If technology and social values always trump property (and do so absent compensation), then what is property's value as a bastion against the arbitrary power of the state? How does one prevent the tyranny of the majority? Are there inviolate first principles?

There are no easy answers to these questions. Instead intense social conflict over these matters continues. Some contemporary advocates suggest that the American concept of strong private property rights is not only appropriate for the US but that it should be internationalised. And in so doing, issues bedevilling the planet - such as massive informal settlements which are the site of massive urban poverty in global mega-cities - could be successfully addressed (see, most prominently de Soto, 2000). Other contemporary advocates argue that it is precisely strong private property rights that produce large scale land use problems, and the only way to solve these problems is through a radical restructuring of what it means to own and control land (see, for example, some of the chapters in Jacobs, 2004, and the manifesto by Alexander et al., 2009).

This latter position draws from both legal opinions and ethical writings born from the post 1970 environmental movement. For example, in a dissent in a 1972 US Supreme Court decision, Justice William O. Douglas wrote 'contemporary public concern for protecting nature's ecological equilibrium should lead to the conferral of standing upon environmental objects to sue for their own protection' (Sierra Club v. Morton, 1972: 741-42). Also in 1972 the State of Wisconsin Supreme Court concluded that 'An owner of land has no absolute and unlimited right to change the essential natural character of his land so as to use it for a purpose for which it was unsuited in its natural state and which injures the rights of others' (Just v. Marinette, 1972: 17; Large, 1973). And these legal actions themselves draw from an ecological and ethical literature that call for a new view of land, less commodity based and more community based, a view which gives to the land a right to existence on its own term (Leopold, 1949; Stone, 1974; Alexander, 1997; Jacobs, 2018).

\section{Conclusion}

But whose land is it? It turns out that this is not an easy question to answer. If a parcel was ever the purview of the owner, it is no longer. In modern times, land belongs to the owner of record and it also belongs to many others. The legacy of the American founders left a confusion about land and property, a confusion even more acute today. Ownership is more fragmented than is commonly acknowledged. Land has more claims upon it, and society has ever more difficulty sorting out the legitimacy of these conflicting claims.

The only way Americans have learned to answer questions about citizenship and land is to continually come together and argue this through - to use a social, dialogical, 
democratic process to address an issue with complex legal, economic and cultural roots. There is no simple economic or legal formula to turn to for answers. Each community in each generation decides on the balance point that respects the rights of the land owner and those of other citizens. Is this a messy process? Yes. Does it guarantee that everyone will be satisfied? No. Is there any other alternative? There does not appear to be.

We do know something about the future: the rights in land and private property will not stagnate. They never have, and they will not now. Land and private property will continue to evolve in America; they have to (Jacobs, 2009). As they do, so too will citizenship claims. Private property represents a social contract. It establishes the rights of the individual and it binds society. The balance point between individual and social rights in property will continually be renegotiated. Each time it is renegotiated, the claimants will be reshuffled.

As Americans continue to reinvent their concept of freedom, of what it means to have liberty, they will come to understand anew what it means to hold land while living in a democratic society. Conflicting claims about citizenship and land become one of the most obvious expressions of this ever-changing dialogue.

\section{Acknowledgments}

The author thanks the editors for encouraging and facilitating my participation in this project.

\section{Notes}

1 I say 'so-called' private property rights movement because the movement has gone through a set of identify evolutions, referring to itself as 'the wise use movement', 'the land rights movement', 'the property rights movement', and 'the private property rights movement'. The latter two have become interchangeable, and now largely replaced the first two. For 'the wise use movement' see Helvarg, 1994, and Echeverria and Eby, 1995; for 'the land rights movement' see for example Yandle, 1995.

2 During the colonial period the Founders took the position that rights to land ownership accrued through use, and freely constituted governments (i.e. democracies) existed for the protection of individual liberties, including the liberty to own and use land. They utilised this idea of active use to provide the justification for taking land from America's native inhabitants. From their point of view, they did not understand the American natives to be using land in the European sense of active agricultural and forest management; see Cronon, 1983.

3 New York City's 1916 zoning ordinance grew out of a study tour of European approaches to urban land management, and draws most heavily from the German experience. For the history of zoning see, for example, Bassett, 1922, Wolf, 2008, and Hirt, 2015.

4 Hardin himself and his intellectual allies used his formulation to argue for a private property rights solution to the tragedy of the commons ("The tragedy of the commons ... is averted by private property ..." Hardin, 1968: 1245). However, the environmental community (broadly defined) has used Hardin's formulation to make the argument for why environmental problems arise (individuals and individual units (such as local governments) acting rationally seek their own best interest, but the cumulation of these actions do not result in the greater social interest; see, for example, Sinden, 2007. So these advocates take one part of Hardin - his analysis of why a problem arises - without accepting his proposed solution.

5 There is a very large literature on the U.S. policy and judicial discourse on public regulatory authority, and its interaction with Justice Holmes' limit as articulated in the Pennsylvania Coal case. 
Strong et al. (1996) engage a set of late twentieth century cases in the pre-Kelo and pre-Tahoe-Sierra period.

6 The phenomenon of displacement for reinvestment received a great deal of international attention in the early 2000s, when the US Supreme Court allowed for the expropriation of a neighbourhood (115 privately owned parcels) for the purpose of economic redevelopment. Once consolidated by the municipality these parcels were to be transferred to a new private owner: Kelo v. City of New London, 545 U.S. 469 (2005). The Court's actions were loudly condemned by political conservatives as an unjustified assault upon private property rights. Yet in the early 1980s, the State of Michigan Supreme Court had allowed for the same type of action to occur in Detroit - Poletown Neighborhood Council v. City of Detroit 410 Mich. 616, 304 N.W.2d 455, 1981. In this instance, the court's action was condemned by political progressives. Even though the Poletown case was reversed by the Michigan court twenty plus years later, in the year before Kelo was decided, in the case of County of Wayne v. Hathcock, 679 N.W.2d 68 (Mich. 2004), the US Supreme Court still relied on the core reasoning in the original Poletown case (see, Delogu, 2006). For more on Kelo, from a conservative perspective, see Benedict, 2009 and Somin, 2015; for the background story on Poletown see Wylie, 1989.

\section{References}

Alexander, G. S. (1997) Commodity and Propriety: Competing Visions of Property in American Legal Thought, 1776-1970, Chicago: University of Chicago Press.

Alexander, G. S., Peñalver, E. M., Singer, J. W. and Underkuffler, L. S. (2009) 'A statement on progressive property', Cornell Law Review 94, 4, 743-4.

Bassett, E. M. (1922) Zoning, Technical Pamphlet Series No. 5, New York: National Municipal League. Bell, L. (1928-1929) 'Air rights', Illinois Law Review, 23, 3, 250-64.

Benedict, J. (2009) Little Pink House: A True Story of Defiance and Courage, New York: Grand Central Publishing.

Bethell, T. (1998) The Noblest Triumph: Property and Prosperity Through the Ages, New York: St. Martin's Press.

Bosselman, F., Callies, D. and Banta, J. (1973) The Taking Issue: An Analysis of the Constitutional Limits of Land Use Control, Washington, D.C.: United States Government Printing Office.

Collier, C. (1992) 'The American people as Christian white men of property: suffrage and elections in colonial and early national America', in D. W. Rogers and C. B. Scriabine, (eds.), Voting and the Spirit of American Democracy: Essays on the History of Voting and Voting Rights in America, Urbana: University of Illinois Press, 19-29.

Cronon, W. (1983) Changes in the Land: Indians, Colonists, and the Ecology of New England, New York: Hill and Wang.

Echeverria, J. and Eby, R. (eds.) (1995) Let the People Judge: A Reader on the Wise Use Movement, Washington, D.C.: Island Press.

de Soto, H. (2000) The Mystery of Capital: Why Capitalism Triumphs in the West and Fails Everywhere Else, New York: Basic Books.

Delogu, O. E. (2006) 'Kelo v. City of New London-Wrongly decided and a missed opportunity for principled line drawing with respect to eminent domain takings', Maine Law Review 58, 1, 18-48.

Ely, Jr., J. W. (1992) The Guardian of Every Other Right: A Constitutional History of Property Rights, New York: Oxford University Press.

Emerson, K. and Wise, C. R. (1997) 'Statutory approaches to regulatory takings: state property rights legislation issues and implications for public administration', Public Administration Review, 57, 5, $411-22$.

Epstein, R. A. (1985) Takings, Private Property and the Power of Eminent Domain, Cambridge: Harvard University Press. 
Foner, E. (1992) 'From slavery to citizenship: blacks and the right to vote', in D. W. Rogers and C. B. Scriabine (eds.), Voting and the Spirit of American Democracy: Essays on the History of Voting and Voting Rights in America, Urbana: University of Illinois Press, 55-65.

Franklin, B. (1907 [1789]) 'Queries and remarks respecting alterations in the constitution of Pennsylvania', in A. H. Smith (ed.), The Writings of Benjamin Franklin, Vol. 10, London: Macmillan and Co.

Gates, P. W. (1936) 'The homestead law in an incongruous land system', The American Historical Review, 41, 4, 652-81.

Geisler, C. C. (1995) 'Land and poverty in the United States: insights and oversights', Land Economics, 71, 1, $16-34$

Gilreath, J. (ed.) (1999) Thomas Jefferson and the Education of a Citizen, Washington, D.C.: Library of Congress.

Gordon, W. (1931) 'History of zoning', The Annals of the American Academy of Political and Social Science, 155, 2, 1-14.

Helvarg, D. (1994) The War Against the Greens: The "Wise Use" Movement, The New Right and Anti-Environmental Violence, San Francisco, CA: Sierra Club Books.

Hamilton, A., Madison, J. and Jay, J. (1961 [1788]) The Federalist Papers, New York: Mentor Books.

Hardin, G. (1968) 'The tragedy of the commons', Science, 162, December, 1243-48.

Heiman, M. K. (1988) The Quiet Evolution: Power, Planning and Profits in New York State, New York: Praeger Publishers.

Hirt, S. (2015) Zoned in the USA: The Origins and Implications of American Land-Use Regulation, Ithaca and New York: Cornell University Press.

Jacobs, H. M. (1995) 'The anti-environmental, "wise use" movement in America', Land Use Law and Zoning Digest, 47, 2, 3-8.

Jacobs, H. M. (1998) 'The 'wisdom', but uncertain future, of the wise use movement', in H. M. Jacobs (ed.), Who Owns America? Social Conflict over Property Rights, Madison, WI: University of Wisconsin Press, 29-44.

Jacobs, H. M. (1999) 'Fighting over land: America's legacy... America's future', Journal of the American Planning Association, 65, 2, 141-49.

Jacobs, H. M. (ed.) (2004) Private Property in the Twenty-first Century: The Future of an American Ideal, Northampton, MA: Edward Elgar.

Jacobs, H. M. (2009) 'Private property in the 22nd century', Planning, 75, 5, 24.

Jacobs, H. M. (2010) 'Social conflict over property rights: the end, a new beginning or a continuing conversation?', Housing Policy Debate, 20, 3, 329-49.

Jacobs, H. M. (2018) 'Eighteenth-century property rights for twenty-first-century environmental conditions?', in F. van der Straalen, T. Hartmann and J. Sheehan (eds.), Property Rights and Climate Change: Land-Use Under Changing Environmental Conditions, New York: Routledge, 41-51.

Jacobs, H. M. and Bassett, E. M. (2011) 'All sound, no fury? The impacts of state-based Kelo laws', Planning and Environmental Law, 63, 2, 3-8.

Johnson, D. H. N (1965) Rights in Air Space, Manchester: Manchester University Press.

Just v. Marinette County (1972) 56 Wis.2d: 7-26.

Large, D. W. (1973) 'This land is whose land? Changing concepts of land as property', Wisconsin Law Review, 4, 1041-83.

Leopold, A. (1949) A Sand County Almanac, London and New York: Oxford University Press.

Marzulla, N. G. (1996) 'Property rights movement: how it began and where it is headed', in P. D. Brick and R. McGreggor Cawley (eds.), A Wolf in the Garden: The Land Rights Movement and the New Environmental Debate, Lanham, MD: Rowman and Littlefield, 39-58.

McClaughry, J. (1975) 'The new feudalism', Environmental Law, 5, 3, 675-702.

McClaughry, J. (1976) 'Farmers, freedom, and feudalism: how to avoid the coming serfdom', South Dakota Law Review, 21, 3, 486-541. 
Oubre, C. F. (1978) Forty Acres and a Mule: The Freedmen's Bureau and Black Land Ownership, Baton Rouge: Louisiana State University Press.

Pennsylvania Coal Co. v. Mahon (1922) 260 U.S. 393-422.

Revell, K. D. (1999) 'The road to Euclid v. Ambler: city planning, state-building, and the changing scope of the police power', Studies in American Political Development, 13, 1, 50-145.

Riis, J. A. (1890) How the Other Half Lives, New York: C. Scribners Sons.

Sandefur, T. (2006) Cornerstone of Liberty: Property Rights in Twenty-first Century America, Washington, D.C., Cato Institute.

Sierra Club v. Morton. (1972) 405 U.S. 727-760.

Sinden, A. (2007) 'The tragedy of the commons and the myth of a private property solution', University of Colorado Law Review, 78, 2, 533-612.

Somin, I. (2015) The Grasping Hand: Kelo v. City of New London and the Limits of Eminent Domain, Chicago: University of Chicago Press.

Stone, C. D. (1974) Should Trees Have Standing? Toward Legal Rights for Natural Objects, Los Altos, CA: W. Kaufmann.

Strong, A. L., Mandelker, D. L. and Kelly, E. D. (1996) 'Property rights and takings', Journal of the American Planning Association, 62, 1, 5-16.

Tahoe-Sierra Preservation Council, Inc. v. Tahoe Regional Planning Agency. (2002) 535 U.S. 302-356.

Treanor, W. M. (1995) 'The original understanding of the takings clause and the political process', Columbia Law Review, 95, 4, 782-887.

Village of Euclid v. Ambler Realty, Co. (1926) 272 U.S. 365-397.

Warp, G. A. (1941-1942) 'Legal status of rural zoning,' Illinois Law Review, 36, 1, 153-70.

Wilson, F. G. (1957-1958) 'Zoning for forestry and recreation: Wisconsin's pioneer role', The Wisconsin Magazine of History, 41, 2, 102-06.

Wolf, M. A. (2008) The Zoning of America: Euclid v. Ambler, Lawrence, KS: University of Kansas Press.

Wylie, J. (1989) Poletown: A Community Betrayed, Urbana, IL: University of Illinois Press.

Yandle, B. (ed.) (1995) Land Rights: The 1990s Property Rights Rebellion, Lanham, MD: Rowman and Littlefield. 